\title{
Metabolic phenotyping for understanding the gut microbiome and host metabolic interplay
}

Article

Accepted Version

Basson, A. R. and Wijeyesekera, A. (2017) Metabolic phenotyping for understanding the gut microbiome and host metabolic interplay. Emerging Topics in Life Sciences, 1 (4). pp. 325-332. ISSN 2397-8562 doi:

https://doi.org/10.1042/ETLS20170079 Available at https://centaur.reading.ac.uk/73737/

It is advisable to refer to the publisher's version if you intend to cite from the work. See Guidance on citing.

To link to this article DOI: http://dx.doi.org/10.1042/ETLS20170079

Publisher: Portland Press

All outputs in CentAUR are protected by Intellectual Property Rights law, including copyright law. Copyright and IPR is retained by the creators or other copyright holders. Terms and conditions for use of this material are defined in the End User Agreement.

www.reading.ac.uk/centaur 
Central Archive at the University of Reading

Reading's research outputs online 


\title{
Metabolic Phenotyping for Understanding the Gut Microbiome
}

\section{and Host Metabolic Interplay}

\author{
Abigail R Basson ${ }^{1}$ and Anisha Wijeyesekera ${ }^{1 *}$ \\ ${ }^{1}$ Food Microbial Sciences Unit, Department of Food and Nutritional Sciences, School \\ of Chemistry, Food \& Pharmacy, University of Reading, Whiteknights, RG6 6AP, \\ United Kingdom
}

“Corresponding Author (a.wijeyesekera@reading.ac.uk)

\begin{abstract}
There is growing interest in the role of the gut microbiome in human health and disease. This unique complex ecosystem has been implicated in a number of health conditions including intestinal disorders, inflammatory skin diseases and metabolic syndrome. However, there is still much to learn regarding its capacity to affect host health. Many gut microbiome research studies focus on compositional analysis to better understand the causal relationships between microbial communities and disease phenotypes. Yet microbial diversity and complexity is such, that community structure alone does not provide full understanding of microbial function.
\end{abstract}

Metabolic phenotyping is an exciting field in systems biology that provides information on metabolic outputs taking place in the system at a given moment in time. These readouts provide information relating to by-products of endogenous metabolic pathways, exogenous signals arising from diet, drugs and other lifestyle and environmental stimuli, as well as products of microbe-host co-metabolism. Thus, better understanding of the gut microbiome and host metabolic interplay can be gleaned by using such analytical approaches.

In this Review, we describe research findings focussed on gut microbiota-host interactions, for functional insight into the impact of microbiome composition on host health. We evaluate different analytical approaches for capturing metabolic activity, and discuss analytical methodological advancements that have made a contribution to the field. This information will aid in developing novel approaches to improve host health in the future, and therapeutic modulation of the microbiome may soon augment conventional clinical strategies. 


\section{Abbreviations}

GC: Gas Chromatography

${ }^{1} \mathrm{H}-\mathrm{NMR}$ : Proton Nuclear Magnetic Resonance

IBD: Inflammatory Bowel Disease

IBS: Irritable Bowel Syndrome

LC: Liquid Chromatography

MCFA: Medium Chain Fatty Acid

MRM: Multiple Reaction Monitoring

MS: Mass Spectrometry

SCFA: Short Chain Fatty Acid

The human gut contains the most metabolically active microbial community in the human body, providing innumerable benefits to host health. Humans depend on gut microorganisms for the digestion of complex carbohydrates and fermentation of resistant starch plant polysaccharides. These include cellulose, xylans and inulin, which are fermented to yield short chain fatty acids (SCFAs) as well as energy. The role of the microbiome is often attributed to the digestion of food and extraction of nutrients. However, it is also linked to hormone regulation, behavioural activity (1-3), and immune system functions (to up to $70 \%$ ) (4). Many beneficial effects of the gut microbiome such as immune homeostasis and host protection from pathogens, are exerted through the interplay between gut and host metabolism. Studies in germ-free rats have shown decreases in intestinal levels of SCFAs (5), demonstrating the importance of the microbiota in energy metabolism. Furthermore, host metabolic activities that are inter-twined with the gut can be affected by disease state, lifestyle, age and diet; as evidenced in metabolic syndrome (6) Inflammatory Bowel Disease (IBD) (7) and liver disease (8). Unravelling the close interplay between host and its tiny intestinal residents, will be invaluable in developing and shaping our understanding of the many facets of the microbiome, and its role in host health. 
In recent years, the extent to which host and microbial metabolism are associated has been studied extensively. Bi-directional interaction between the two begins at birth (9) with the immediate shaping of the immune system (10). Experiments in germ-free mice have demonstrated the devastating effects of birth with no immediate microbial colonisation, and highlights the importance of a symbiotic relationship (11). Different gut populations exist in different regions of the large intestine, and therefore chemical cross talk between the host and gut varies. Unique signalling of low molecular weight metabolites from the gut to different regions of the body take place via multi-directional communication highways, including gut-brain, gut-lung and gut-skin axes (12-14). Furthermore, disruption of this metabolic conversation and mutualistic relationship (a state termed dysbiosis) has been used to explain the rise in several health conditions such as obesity, type 2 diabetes, asthma, IBD, liver disease and cancer $(15,16)$.

SCFAs (primarily, butyrate, acetate and propionate) have been demonstrated to be extremely important in maintaining colonic health. Butyrate is the preferred energy source for colonocytes, with published literature providing evidence that an increase in butyrate absorption in the gut can decrease the risk of cancer development through stimulation of intestinal epithelial goblet cells (by increased transcription of mucin glycoprotein genes), thereby strengthening the colonic defence barrier (17). Additionally, these metabolites exhibit anti-inflammatory effects and have been shown to regulate the movement and function of neutrophils. For example, butyrate has been shown to inhibit growth of pathogenic species of bacteria by reducing the $\mathrm{pH}(18)$, acetate in the stimulation of peristaltic activity and intestinal motility, whilst propionate has been reported to hold antimicrobial properties (19).

Further experiments focussing on functional assessment of the microbiome can build on this knowledge and better understand the implication of changes in bacterial composition on host health $(20,21)$. This information can potentially be used to treat disease in the future, through therapeutic modulation of the microbiota $(22,23)$.

\section{Metabolic Phenotyping}

Metabolic phenotyping is an established top-down systems approach for highthroughput detection and quantification of low molecular weight molecules present in body fluids (such as urine and blood plasma/serum), stool and tissues (e.g. biopsies) $(24,25)$ at any given moment in time. This system-wide molecular characterisation 
enables discrimination between healthy and diseased individuals based on differences in metabolic phenotype (26). Metabolites detected include small, intermediate and end by-products of endogenous metabolic pathways, but also, products of microbe-host co-metabolism (e.g. SCFAs), and exogenous signals arising from diet, drugs and other lifestyle and environmental stimuli (27). Capturing changes in bacterially-produced metabolites and other microbial co-metabolites following these and other exposures such as environmental stresses, antibiotics and pre-, pro- and symbiotic intake (22), provides functional insight into the impact of microbiome composition on host health (28). Thus, the approach is ideally suited for better understanding the gut microbiome and host metabolic interplay, augmenting and complementing information obtained from metataxonomics and metagenomics, to gain deeper insight into microbiome function $(29,30)$.

The major analytical platforms used in metabolic phenotyping are ${ }^{1} \mathrm{H}$-Nuclear Magnetic Resonance ( ${ }^{1} \mathrm{H}-\mathrm{NMR}$ ) Spectroscopy (31) and Mass Spectrometry (MS). MS can be hyphenated with chromatographic separation techniques such as Gas Chromatography (GC) and Liquid Chromatography (LC) for prior separation of molecules followed by detection. Samples can also be analysed directly using direct infusion (for biofluids) or imaging (for tissues) MS techniques (32). NMR and MS analytical technologies enable simultaneous capture of information on hundreds or thousands of metabolites from a single biological sample. Urine and faecal samples mostly contain information on metabolic end products (including those produced from bacteria), whereas blood serum and plasma provide information on circulating metabolites. Acquired spectral data captures presence or absence of these low molecular weight molecules, as well as metabolite concentration (which can be over a wide range within a sample, especially in diseased states where there may be additional chemical signals at high intensity due to pathophysiology, or from therapeutic intervention (e.g. drugs or diet). Thus, experimental design and selection of the most appropriate analytical strategy is essential for optimal information recovery $(33,34)$. Indeed, there are a growing number of studies utilising a multi-platform approach for more comprehensive characterisation of metabolic phenotype $(35,36)$. Analysis of this data enables a holistic insight into systems-level processes, and better understanding of physiological and pathophysiological disease mechanisms. In 
particular, identification of metabolites produced as a result of microbial-mammalian co-metabolism furthers understanding of host-gut interactions $(37,38)$.

\section{Untargeted Metabolic Phenotyping}

Untargeted metabolic phenotyping is often initially used in metabonomics and metabolomics studies, as a "hypothesis generating" approach. This analytical strategy using NMR and/or MS technologies, does not pre-select compounds to be detected, in order to capture unspecified, untargeted spectral profiles (or fingerprints) containing information on all the metabolites detectable by the respective analytical platform (31, 39). The benefit of using an untargeted approach, is that it has the potential to uncover novel information which may have been outside the limits of targeted analysis, identifying prospective diagnostic and/or prognostic biomarkers of disease $(40,41)$, and molecular mechanisms arising as a result of gut-host interactions (42). Table 1 summarises a selection of research studies using an untargeted metabolic phenotyping approach, that have contributed to the understanding of metabolic cross talk between gut microbes and the host, in a variety of health conditions and disease states.

\begin{tabular}{|c|c|c|c|}
\hline Study & $\begin{array}{l}\text { Analytical } \\
\text { Approach }\end{array}$ & $\begin{array}{l}\text { Study Results/Key } \\
\text { Findings }\end{array}$ & Reference \\
\hline $\begin{array}{l}\text { Effect of } \\
\text { bariatric surgery } \\
\text { on gut-host } \\
\text { metabolic cross } \\
\text { talk }\end{array}$ & $\begin{array}{l}{ }^{1} \mathrm{H}-\mathrm{NMR} \text { based } \\
\text { metabolic } \\
\text { phenotyping of urine } \\
\text { and faecal water } \\
\text { samples, and } \\
\text { pyrosequencing of } \\
\text { faecal samples pre- } \\
\text { and post- surgery }\end{array}$ & $\begin{array}{l}\text { - Increase in a number of } \\
\text { metabolites post bariatric } \\
\text { surgery, with several of } \\
\text { those deriving from } \\
\text { mammalian microbial co- } \\
\text { metabolism - } \\
\text { demonstrated by an } \\
\text { increase in diversity and } \\
\text { complexity of signals in } \\
\text { the aromatic region of the } \\
{ }^{1} \mathrm{H}-\mathrm{NMR} \text { urinary spectra. } \\
\text { - As metabolites derived } \\
\text { from microbial }\end{array}$ & (43) \\
\hline
\end{tabular}




\begin{tabular}{|c|c|c|c|}
\hline & & $\begin{array}{l}\text { fermentation increased, } \\
\text { body weight decreased. }\end{array}$ & \\
\hline $\begin{array}{l}\text { Fingerprinting of } \\
\text { the human gut } \\
\text { phenotype }\end{array}$ & $\begin{array}{l}\text { LC-MS metabolic } \\
\text { phenotyping of } \\
\text { faecal samples and } \\
\text { extracts taken from } \\
\text { an in vitro human } \\
\text { gastrointestinal tract } \\
\text { model }\end{array}$ & $\begin{array}{l}\text { - Method enabled broad } \\
\text { coverage of the faecal } \\
\text { metabolome (9553 MS } \\
\text { features detected). } \\
\text { - Analysis of in vitro model } \\
\text { extracts following addition } \\
\text { of antibiotics, revealed } \\
\text { metabolic changes linked } \\
\text { to a shift in microbial } \\
\text { diversity. }\end{array}$ & (38) \\
\hline $\begin{array}{l}\text { Metabolic } \\
\text { activity of the } \\
\text { gut microbiome } \\
\text { in Ulcerative } \\
\text { Colitis (UC) and } \\
\text { Irritable Bowel } \\
\text { Syndrome (IBS) }\end{array}$ & $\begin{array}{l}{ }^{1} \mathrm{H}-\mathrm{NMR} \text { metabolic } \\
\text { phenotyping and } \\
\text { PCR-denaturing } \\
\text { gradient gel } \\
\text { electrophoresis } \\
\text { (PCR-DGGE) } \\
\text { analysis of faecal } \\
\text { samples from } \\
\text { healthy and disease } \\
\text { (UC and IBS) state } \\
\text { patients }\end{array}$ & $\begin{array}{l}\text { - Differences in faecal } \\
\text { metabolic profiles } \\
\text { between healthy and } \\
\text { disease states included } \\
\text { glucose, amines, fatty } \\
\text { acids and bile acids. } \\
\text { - Correlation seen between } \\
\text { gut microbiota } \\
\text { composition and } \\
\text { metabolite profiles. }\end{array}$ & (44) \\
\hline $\begin{array}{l}\text { Characterisation } \\
\text { of an obese } \\
\text { associated } \\
\text { metabolic } \\
\text { phenotype }\end{array}$ & $\begin{array}{l}{ }^{1} \mathrm{H}-\mathrm{NMR} \text { metabolic } \\
\text { phenotyping of urine } \\
\text { collected from } \\
\text { obese patients } \\
\text { compared to lean } \\
\text { controls }\end{array}$ & $\begin{array}{l}\text { - Discrimination of urinary } \\
\text { metabolic phenotypes } \\
\text { based primarily on } \\
\text { differences in hippuric } \\
\text { acid, trigonelline, 2- } \\
\text { hydroxyisobutyrate and } \\
\text { xanthine. } \\
\text { - Following bariatric } \\
\text { surgery, the obese }\end{array}$ & (36) \\
\hline
\end{tabular}




\begin{tabular}{|c|c|c|c|}
\hline & & $\begin{array}{l}\text { associated metabolic } \\
\text { phenotype is altered. } \\
\text { - These results confirm that } \\
\text { gut microbiome } \\
\text { metabolism is strongly } \\
\text { linked with human host } \\
\text { metabolism. }\end{array}$ & \\
\hline $\begin{array}{l}\text { Microbial and } \\
\text { metabolic } \\
\text { molecular } \\
\text { phenotyping to } \\
\text { assess IBD risk }\end{array}$ & $\begin{array}{l}\text { LC-MS metabolic } \\
\text { phenotyping and } \\
16 S \text { ribosomal RNA } \\
\text { gene sequencing of } \\
\text { faecal samples } \\
\text { collected from } \\
\text { families of paediatric } \\
\text { IBD patients }\end{array}$ & $\begin{array}{l}\text { - Identification of two } \\
\text { microbial and metabolic } \\
\text { phenotypes in first degree } \\
\text { relatives of paediatric IBD } \\
\text { patients. } \\
\text { - An IBD-associated } \\
\text { molecular phenotype in } \\
\text { healthy relatives suggests } \\
\text { that shared genetic } \\
\text { and/or environmental } \\
\text { factors within families can } \\
\text { be a pre-existing trait that } \\
\text { precedes the acquisition } \\
\text { of disease. }\end{array}$ & (45) \\
\hline
\end{tabular}

Table 1: Summary of some research studies conducted to date using untargeted metabolic phenotyping techniques, which further our understand of the gut microbiome-host metabolic interplay.

\section{Targeted Metabolic Phenotyping}

In "hypothesis driven" metabolic phenotyping studies (where targeted detection and quantification of specific metabolites of interest are required), MS is often the technology of choice over NMR. Despite improvements in instrument technology and both NMR and MS having the capability to conduct quantitative analyses, MS is still considered to be superior in terms of sensitivity, and most MS systems can be configured to capture specific molecules only, thereby providing selectivity (46). 
Triple quadrupole MS instruments using Multiple Reaction Monitoring (MRM) are often used in targeted metabolic phenotyping studies, for enhanced sensitivity and selectivity. Here, the first and third quadrupoles of the MS instrument filters ions that have a different mass to charge ratio $(\mathrm{m} / \mathrm{z})$ than that of the desired ion of interest, resulting in targeted capture. Furthermore, the instrument can easily be coupled to chromatographic systems for prior separation of compounds of interest before MS detection, resulting in more focussed analysis. For example, GC coupled to MS would be ideally suited to capture volatile compounds, whereas polar compounds are better analysed by LC separation followed by MS detection. The addition of stable isotope chemical standards to biological study samples enables absolute quantification of metabolites. This approach is of growing interest and value, as the data can provide new reference range values.

The development of targeted metabolic phenotyping methods to capture specific metabolites known to interact with the gut microbiome has deepened our understanding of the mechanisms leading to disease. In particular, this has shown promise in clinical research applications as it enables rapid measurement of several biomarkers in a single analytical run (rather than conducting several independent assays) from a single biological sample. Thus, reduces cost, saves time as well as sample volume requirement (often an issue in the case of studies where sample volume is limited). Furthermore, the sensitivity and specificity reported in studies conducted so far demonstrate its potential to possibly replace conventional lab-based clinical assays in the future $(47,48)$. A summary of recent research developments is given in Table 2.

\begin{tabular}{|c|c|c|c|}
\hline Study & Analytical Approach & $\begin{array}{l}\text { Key findings } \\
\text { /Conclusion }\end{array}$ & Reference \\
\hline $\begin{array}{l}\text { Characterisation } \\
\text { of metabolic } \\
\text { signatures in } \\
\text { paediatric IBD } \\
\text { patients, using } \\
\text { non-invasively }\end{array}$ & $\begin{array}{l}\text { Urinary bile acid } \\
\text { quantification (LC-MS) } \\
\text { and untargeted } \\
\text { analysis conducted in } \\
\text { parallel (GC-MS) }\end{array}$ & $\begin{array}{l}\text { - Identified a unique } \\
\text { urinary signature of } \\
\text { paediatric IBD } \\
\text { - Differences include } \\
\text { central energy } \\
\text { metabolism, amino }\end{array}$ & (49) \\
\hline
\end{tabular}




\begin{tabular}{|c|c|c|c|}
\hline $\begin{array}{l}\text { collected urine } \\
\text { samples }\end{array}$ & & $\begin{array}{l}\text { acids, bile acids and gut } \\
\text { microbial metabolites }\end{array}$ & \\
\hline $\begin{array}{l}\text { Analysis of the } \\
\text { faecal } \\
\text { metabolome to } \\
\text { identify volatile } \\
\text { biomarkers in Gl } \\
\text { diseases, that } \\
\text { are } \\
\text { hypothesised to } \\
\text { be produced by } \\
\text { Clostridium } \\
\text { difficile and } \\
\text { Campylobacter } \\
\text { jejuni, during } \\
\text { infections. }\end{array}$ & $\begin{array}{l}\text { Faecal volatile organic } \\
\text { compound analysis } \\
\text { (GC-MS). }\end{array}$ & $\begin{array}{l}\text { - Detected } 297 \text { faecal } \\
\text { volatile compounds that } \\
\text { discriminate between } \\
\text { control and infected } \\
\text { individuals' samples } \\
\text { - Of particular interest is } \\
\text { the presence of } \\
\text { butanoic acid in all } \\
\text { groups except } C \text {. } \\
\text { difficile samples }\end{array}$ & $(50)$ \\
\hline $\begin{array}{l}\text { Assessment of } \\
\text { the influence of } \\
\text { indolic } \\
\text { compounds } \\
\text { (associated with } \\
\text { commensal } \\
\text { bacterial and } \\
\text { plant } \\
\text { metabolism) on } \\
\text { human } \\
\text { disorders of } \\
\text { tyrosine } \\
\text { metabolism }\end{array}$ & $\begin{array}{l}\text { Quantification of } \\
\text { plasma indolic } \\
\text { compounds alongside } \\
\text { untargeted analysis } \\
\text { (LC-MS). }\end{array}$ & $\begin{array}{l}\text { - Elevation of several } \\
\text { indolic compounds in } \\
\text { patient sera } \\
\text { - Identified that the } \\
\text { downstream indole } \\
\text { metabolite, } \\
\text { indolecarboxaldehyde, } \\
\text { was produced } \\
\text { exclusively by } \\
\text { commensal gut } \\
\text { bacteria. }\end{array}$ & (51) \\
\hline
\end{tabular}




\begin{tabular}{|c|c|c|c|}
\hline $\begin{array}{l}\text { Development of } \\
\text { a targeted } \\
\text { method for } \\
\text { quantification of } \\
\text { short and } \\
\text { medium chain } \\
\text { fatty acids } \\
\text { (MCFAs) in } \\
\text { plasma, faeces } \\
\text { and faecal } \\
\text { fermentation } \\
\text { samples }\end{array}$ & $\begin{array}{l}\text { SCFA and MCFA } \\
\text { quantification (GC- } \\
\text { MS). }\end{array}$ & $\begin{array}{l}\text { - Newly developed } \\
\text { method targets end } \\
\text { products of gut } \\
\text { microbiota fermentation } \\
\text { (SCFAs) as well as } \\
\text { markers of dietary } \\
\text { triglyceride } \\
\text { consumption (MCFAs) } \\
\text { - Capture of multi- } \\
\text { compartment data aids } \\
\text { in understanding } \\
\text { biological mechanisms } \\
\text { at a systems level. }\end{array}$ & (52) \\
\hline $\begin{array}{l}\text { Determination of } \\
\text { compounds } \\
\text { supporting the } \\
\text { antifungal } \\
\text { properties of } \\
\text { lactic acid } \\
\text { bacteria and } \\
\text { propionibacteria }\end{array}$ & $\begin{array}{l}\text { Quantification of } \\
\text { antifungal compounds } \\
\text { in bacterial culture } \\
\text { supernatants (LC-MS). }\end{array}$ & $\begin{array}{l}\text { - Identification of } \\
\text { molecules produced by } \\
\text { lactic acid bacteria and } \\
\text { propionibacteria, that } \\
\text { are responsible for their } \\
\text { antifungal activity. } \\
\text { - Good example of an } \\
\text { analytical approach that } \\
\text { may be applied to other } \\
\text { strains of bacteria, to } \\
\text { better understand } \\
\text { functional activity. }\end{array}$ & (53) \\
\hline
\end{tabular}

Table 2: Studies conducted to understand gut microbiome-host metabolic interplay using targeted metabolic phenotyping approaches

\section{Data Integration}

Published literature has shown that data generated from metabolic phenotyping studies has the capacity to provide us with better understanding of gene-environment interactions (including the influence of the gut microbiota). However, studies have shown that this data can be enriched through fusion with other data such as clinical 
markers, and those generated by other omics technologies (for example, genomics, proteomics, metagenomics etc.). Maximising information recovery enables deeper insight into the biological processes taking place in the entire system, and better understanding of disease mechanisms. For example, in a study by Elliott et al., metabolic data (acquired from urine samples using ${ }^{1} \mathrm{H}-\mathrm{NMR}$ spectroscopy and ion exchange chromatography) were integrated with anthropometric data from a largescale epidemiology study, with a view to better understanding which urinary metabolites contribute to BMI status (in order to characterise a metabolic signature of adiposity) (54). The statistical analysis identified metabolites significantly associated with BMI, implicating an extensive interconnected set of biochemical pathways and physiological processes, as well as involvement of the gut microbiota. As shown in Figure 1, when presented as an integrated metabolic reaction network of human adiposity (using the MetaboNetworks software program (55)), the fused data assisted in visualising metabolic paths linking the identified BMI-associated metabolites. In red boxes are metabolites positively correlated with $\mathrm{BMI}$, and in blue boxes are metabolites negatively correlated. Of particular interest, is the mapping of gut microbial-related BMI markers (orange background) onto several pathways embedded in the host network.

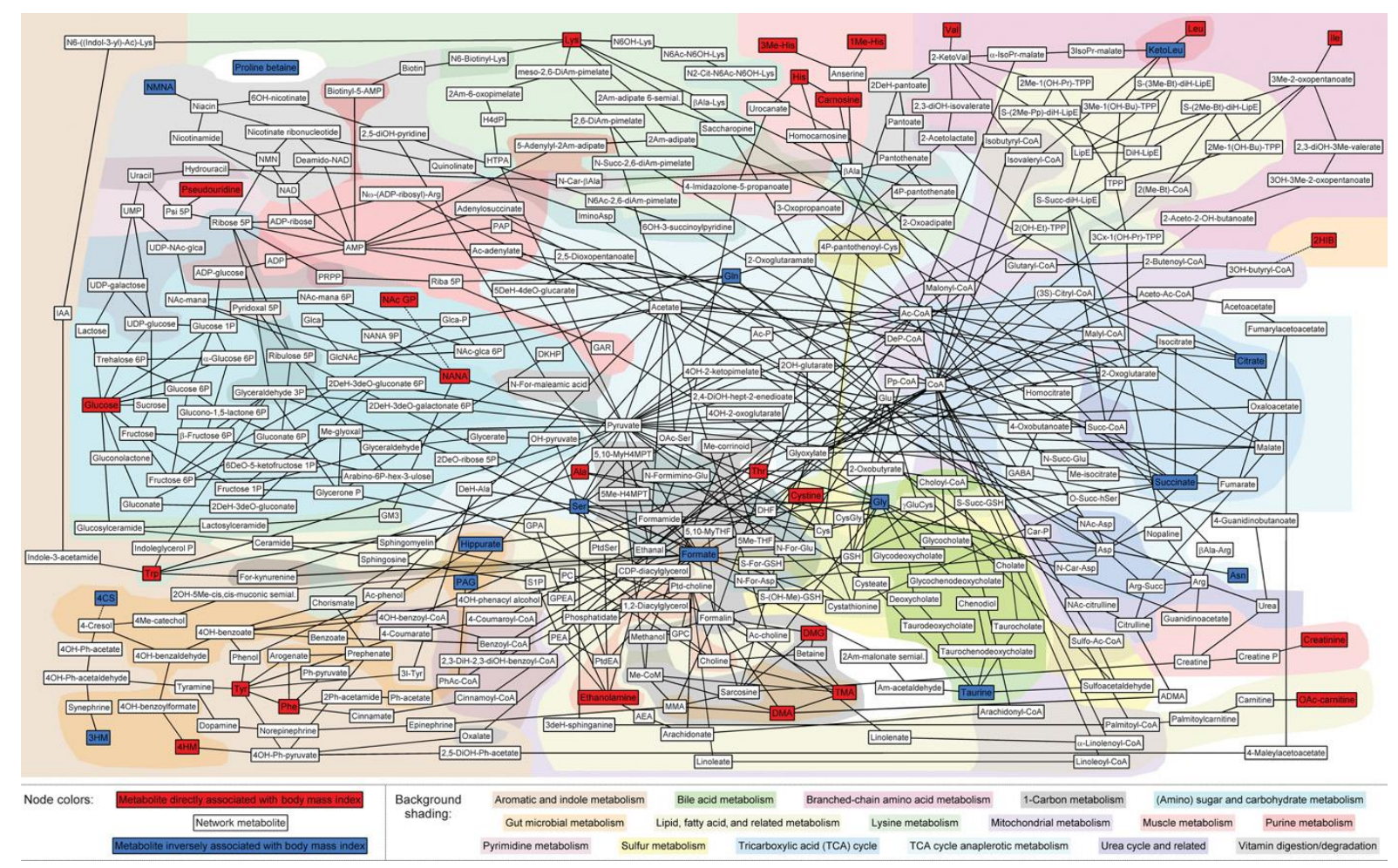


Figure 1: Metabolic reaction network map identifying metabolites associated with $\mathrm{BMI}$ (red = higher BMI, blue = lower BMI) and their interconnectivities in the host system. Background shading visualises different types of metabolism (orange = gut microbial metabolism). Figure reproduced from Elliott et al. (54))

Another example of improved mechanistic understanding through data fusion is demonstrated by Zierer et al., who used a random forest approach to integrate epigenomics, transcriptomics, glycomics and metabolomics datasets together with clinical phenotypes, generating a model that identified distinct molecular markers of the aging process that might drive disease comorbidities (56). This study highlighted the benefits of data integration, as it not only confirmed associations that were identified previously (and modelled independently), but also uncovered potentially novel disease mechanisms. In another data driven approach by Noecker et al., a method for predicting community-wide metabolic turnover was applied to integrated metabolic phenotyping data and $16 \mathrm{~S}$ community profiles, in order to calculate the biosynthetic and degradation potential of a given microbial community. A developed framework then compared predicted metabolic variation potential with actual measured concentrations, to assess whether bacterial composition can explain observed metabolic shifts, and identify key taxa and genes that were contributors to these shifts. The framework was applied to vaginal microbiome as well as gut microbiome datasets where $16 \mathrm{~S}$ community profiling and metabolic phenotyping data were available. The results revealed that well-predicted metabolite variation generally resulted from disease-associated metabolism, and the authors identified several disease-enriched species that contributed to these predictions. Of note, was that the analysis also detected metabolites for which the predicted variation negatively correlated with the measured variation, suggesting environmental regulation of microbial metabolism (57).

\section{Summary Points}

- The gut microbiome still harbours unknown knowledge regarding its capacity to affect human health. This complex ecosystem produces several compounds during metabolism of nutrients and xenobiotics, and fermentation of dietary fibre, some of which interact with host metabolic processes, influencing host health. 
- A clear understanding of these gut-host interactions are necessary for comprehensive understanding of disease aetiology. Metabolic phenotyping approaches provide such an opportunity, capturing targeted as well as novel markers of interest, providing insight into gut-host co-metabolic processes.

- Taken together with microbiology and sequencing techniques, fusion of information provides functional assessment of the microbiome, unravelling the extent of the interplay between gut microbiome and mammalian host which should be exploited for therapeutic benefit.

\section{Acknowledgements}

The authors acknowledge research contributions by the authors cited in this review.

\section{Declaration of Interests}

The authors declare no conflict of interest.

\section{Funding Information}

The authors acknowledge the Department of Food and Nutritional Sciences at the University of Reading for funding support.

\section{Author Contribution}

A.R.B: literature review, manuscript writing and critical review. A.W: manuscript design, manuscript writing and critical review. Both authors agreed upon the final manuscript. 


\section{References}

1. Belkaid $\mathrm{Y}$, Hand TW. Role of the microbiota in immunity and inflammation. Cell. 2014;157(1):121-41.

2. Enders G. Gut: Scribe Publications; 2016.

3. Guarner F, Malagelada JR. Gut flora in health and disease. Lancet. 2003;361(9356):512-9.

4. Ding $T$, Schloss PD. Dynamics and associations of microbial community types across the human body. Nature. 2014;509(7500):357-60.

5. Hoverstad T, Midtvedt T. Short-chain fatty acids in germfree mice and rats. J Nutr. 1986;116(9):1772-6.

6. Cani PD, Delzenne NM. The role of the gut microbiota in energy metabolism and metabolic disease. Curr Pharm Des. 2009;15(13):1546-58.

7. Thorkildsen LT, Nwosu FC, Avershina E, Ricanek P, Perminow G, Brackmann $S$, et al. Dominant fecal microbiota in newly diagnosed untreated inflammatory bowel disease patients. Gastroenterol Res Pract. 2013;2013:636785.

8. Kummen M, Holm K, Anmarkrud JA, Nygard S, Vesterhus M, Hoivik ML, et al. The gut microbial profile in patients with primary sclerosing cholangitis is distinct from patients with ulcerative colitis without biliary disease and healthy controls. Gut. 2017;66(4):611-9.

9. Martin R, Makino H, Cetinyurek Yavuz A, Ben-Amor K, Roelofs M, Ishikawa E, et al. Early-Life Events, Including Mode of Delivery and Type of Feeding, Siblings and Gender, Shape the Developing Gut Microbiota. PLoS One. 2016;11(6):e0158498.

10. Levy M, Thaiss CA, Elinav E. Metagenomic cross-talk: the regulatory interplay between immunogenomics and the microbiome. Genome Med. 2015;7:120.

11. Xu J, Gordon Jl. Honor thy symbionts. Proc Natl Acad Sci U S A. 2003;100(18):10452-9.

12. El Aidy S, Dinan TG, Cryan JF. Gut Microbiota: The Conductor in the Orchestra of Immune-Neuroendocrine Communication. Clin Ther. 2015;37(5):954-67.

13. El Aidy S, Stilling R, Dinan TG, Cryan JF. Microbiome to Brain: Unravelling the Multidirectional Axes of Communication. Adv Exp Med Biol. 2016;874:301-36. 
14. Schroeder BO, Backhed F. Signals from the gut microbiota to distant organs in physiology and disease. Nat Med. 2016;22(10):1079-89.

15. Cho I, Blaser MJ. The human microbiome: at the interface of health and disease. Nat Rev Genet. 2012;13(4):260-70.

16. Marchesi JR, Adams DH, Fava F, Hermes GD, Hirschfield GM, Hold G, et al. The gut microbiota and host health: a new clinical frontier. Gut. 2016;65(2):330-9.

17. Gaudier E, Jarry A, Blottiere HM, de Coppet P, Buisine MP, Aubert JP, et al. Butyrate specifically modulates MUC gene expression in intestinal epithelial goblet cells deprived of glucose. Am J Physiol Gastrointest Liver Physiol. 2004;287(6):G1168-74.

18. Augenlicht L, Shi L, Mariadason J, Laboisse C, Velcich A. Repression of MUC2 gene expression by butyrate, a physiological regulator of intestinal cell maturation. Oncogene. 2003;22(32):4983-92.

19. Yun J, Lee DG. A novel fungal killing mechanism of propionic acid. FEMS Yeast Res. 2016;16(7).

20. Engels C, Ruscheweyh HJ, Beerenwinkel N, Lacroix C, Schwab C. The Common Gut Microbe Eubacterium hallii also Contributes to Intestinal Propionate Formation. Front Microbiol. 2016;7:713.

21. Falony G, Vieira-Silva S, Raes J. Microbiology Meets Big Data: The Case of Gut Microbiota-Derived Trimethylamine. Annu Rev Microbiol. 2015;69:305-21.

22. Holmes E, Kinross J, Gibson GR, Burcelin R, Jia W, Pettersson S, et al. Therapeutic modulation of microbiota-host metabolic interactions. Sci Transl Med. 2012;4(137):137rv6.

23. Liu Y, Gibson GR, Walton GE. An In Vitro Approach to Study Effects of Prebiotics and Probiotics on the Faecal Microbiota and Selected Immune Parameters Relevant to the Elderly. PLoS One. 2016;11(9):e0162604.

24. Nicholson JK, Lindon JC. Systems biology: Metabonomics. Nature. 2008;455(7216):1054-6.

25. Dunn WB, Broadhurst DI, Atherton HJ, Goodacre R, Griffin JL. Systems level studies of mammalian metabolomes: the roles of mass spectrometry and nuclear magnetic resonance spectroscopy. Chem Soc Rev. 2011;40(1):387426. 
26. Nicholson JK, Lindon JC, Holmes E. 'Metabonomics': understanding the metabolic responses of living systems to pathophysiological stimuli via multivariate statistical analysis of biological NMR spectroscopic data. Xenobiotica. 1999;29(11):1181-9.

27. Wild CP. Complementing the genome with an "exposome": the outstanding challenge of environmental exposure measurement in molecular epidemiology. Cancer Epidemiol Biomarkers Prev. 2005;14(8):1847-50.

28. Marcobal A, Kashyap PC, Nelson TA, Aronov PA, Donia MS, Spormann A, et al. A metabolomic view of how the human gut microbiota impacts the host metabolome using humanized and gnotobiotic mice. ISME J. 2013;7(10):1933-43.

29. Nicholson JK, Holmes E, Kinross J, Burcelin R, Gibson G, Jia W, et al. Hostgut microbiota metabolic interactions. Science. 2012;336(6086):1262-7.

30. Ursell LK, Haiser HJ, Van Treuren W, Garg N, Reddivari L, Vanamala J, et al. The intestinal metabolome: an intersection between microbiota and host. Gastroenterology. 2014;146(6):1470-6.

31. Beckonert O, Keun HC, Ebbels TM, Bundy J, Holmes E, Lindon JC, et al. Metabolic profiling, metabolomic and metabonomic procedures for NMR spectroscopy of urine, plasma, serum and tissue extracts. Nat Protoc. 2007;2(11):2692-703.

32. Han J, Datla R, Chan S, Borchers CH. Mass spectrometry-based technologies for high-throughput metabolomics. Bioanalysis. 2009;1(9):166584.

33. Johnson $\mathrm{CH}$, Gonzalez FJ. Challenges and opportunities of metabolomics. J Cell Physiol. 2012;227(8):2975-81.

34. Lindon JC, Nicholson JK. Spectroscopic and statistical techniques for information recovery in metabonomics and metabolomics. Annu Rev Anal Chem (Palo Alto Calif). 2008;1:45-69.

35. Andreas NJ, Hyde MJ, Gomez-Romero M, Lopez-Gonzalvez MA, Villasenor A, Wijeyesekera A, et al. Multiplatform characterization of dynamic changes in breast milk during lactation. Electrophoresis. 2015.

36. Dieme B, Mavel S, Blasco H, Tripi G, Bonnet-Brilhault F, Malvy J, et al. Metabolomics Study of Urine in Autism Spectrum Disorders Using a Multiplatform Analytical Methodology. J Proteome Res. 2015;14(12):5273-82. 
37. Phetcharaburanin J, Lees H, Marchesi JR, Nicholson JK, Holmes E, Seyfried F, et al. Systemic Characterization of an Obese Phenotype in the Zucker Rat Model Defining Metabolic Axes of Energy Metabolism and Host-Microbial Interactions. J Proteome Res. 2016;15(6):1897-906.

38. Vanden Bussche J, Marzorati M, Laukens D, Vanhaecke L. Validated High Resolution Mass Spectrometry-Based Approach for Metabolomic Fingerprinting of the Human Gut Phenotype. Anal Chem. 2015;87(21):1092734.

39. Contrepois K, Jiang L, Snyder M. Optimized Analytical Procedures for the Untargeted Metabolomic Profiling of Human Urine and Plasma by Combining Hydrophilic Interaction (HILIC) and Reverse-Phase Liquid Chromatography (RPLC)-Mass Spectrometry. Mol Cell Proteomics. 2015;14(6):1684-95.

40. Ladep NG, Dona AC, Lewis MR, Crossey MM, Lemoine M, Okeke E, et al. Discovery and validation of urinary metabotypes for the diagnosis of hepatocellular carcinoma in West Africans. Hepatology. 2014;60(4):1291-301.

41. Zeng $\mathrm{H}$, Tong R, Tong W, Yang Q, Qiu M, Xiong A, et al. Metabolic Biomarkers for Prognostic Prediction of Pre-diabetes: results from a longitudinal cohort study. Sci Rep. 2017;7(1):6575.

42. Lichtman JS, Ferreyra JA, Ng KM, Smits SA, Sonnenburg JL, Elias JE. HostMicrobiota Interactions in the Pathogenesis of Antibiotic-Associated Diseases. Cell Rep. 2016;14(5):1049-61.

43. Li JV, Ashrafian H, Bueter M, Kinross J, Sands C, le Roux CW, et al. Metabolic surgery profoundly influences gut microbial-host metabolic crosstalk. Gut. 2011;60(9):1214-23.

44. Le Gall G, Noor SO, Ridgway K, Scovell L, Jamieson C, Johnson IT, et al. Metabolomics of fecal extracts detects altered metabolic activity of gut microbiota in ulcerative colitis and irritable bowel syndrome. J Proteome Res. 2011;10(9):4208-18.

45. Jacobs JP, Goudarzi M, Singh N, Tong M, McHardy IH, Ruegger P, et al. A Disease-Associated Microbial and Metabolomics State in Relatives of Pediatric Inflammatory Bowel Disease Patients. Cell Mol Gastroenterol Hepatol. 2016;2(6):750-66. 
46. Emwas $\mathrm{AH}$. The strengths and weaknesses of NMR spectroscopy and mass spectrometry with particular focus on metabolomics research. Methods Mol Biol. 2015;1277:161-93.

47. Zhang Q, Han L, Wang J, Lin H, Ke P, Zhuang J, et al. Simultaneous quantitation of endogenous estrone, 17beta-estradiol, and estriol in human serum by isotope-dilution liquid chromatography-tandem mass spectrometry for clinical laboratory applications. Anal Bioanal Chem. 2017;409(10):2627-38.

48. Awwad HM, Geisel J, Obeid R. Determination of trimethylamine, trimethylamine $\mathrm{N}$-oxide, and taurine in human plasma and urine by UHPLCMS/MS technique. J Chromatogr B Analyt Technol Biomed Life Sci. 2016;1038:12-8.

49. Martin FP, Su MM, Xie GX, Guiraud SP, Kussmann M, Godin JP, et al. Urinary metabolic insights into host-gut microbial interactions in healthy and IBD children. World J Gastroenterol. 2017;23(20):3643-54.

50. Garner CE, Smith S, de Lacy Costello B, White P, Spencer R, Probert CS, et al. Volatile organic compounds from feces and their potential for diagnosis of gastrointestinal disease. FASEB J. 2007;21(8):1675-88.

51. Gertsman I, Gangoiti JA, Nyhan WL, Barshop BA. Perturbations of tyrosine metabolism promote the indolepyruvate pathway via tryptophan in host and microbiome. Mol Genet Metab. 2015;114(3):431-7.

52. Lotti C, Rubert J, Fava F, Tuohy K, Mattivi F, Vrhovsek U. Development of a fast and cost-effective gas chromatography-mass spectrometry method for the quantification of short-chain and medium-chain fatty acids in human biofluids. Anal Bioanal Chem. 2017.

53. Le Lay C, Coton E, Le Blay G, Chobert JM, Haertle T, Choiset Y, et al. Identification and quantification of antifungal compounds produced by lactic acid bacteria and propionibacteria. Int J Food Microbiol. 2016;239:79-85.

54. Elliott P, Posma JM, Chan Q, Garcia-Perez I, Wijeyesekera A, Bictash M, et al. Urinary metabolic signatures of human adiposity. Sci Transl Med. 2015;7(285):285ra62.

55. Posma JM, Robinette SL, Holmes E, Nicholson JK. MetaboNetworks, an interactive Matlab-based toolbox for creating, customizing and exploring subnetworks from KEGG. Bioinformatics. 2014;30(6):893-5. 
56. Zierer J, Pallister T, Tsai PC, Krumsiek J, Bell JT, Lauc G, et al. Exploring the molecular basis of age-related disease comorbidities using a multi-omics graphical model. Sci Rep. 2016;6:37646.

57. Noecker C, Eng A, Srinivasan S, Theriot CM, Young VB, Jansson JK, et al. Metabolic Model-Based Integration of Microbiome Taxonomic and Metabolomic Profiles Elucidates Mechanistic Links between Ecological and Metabolic Variation. mSystems. 2016;1(1). 